\title{
Effectiveness of Regional Tax Collection (Study of Land and Building Tax Collection of Rural and Urban Areas in Banjarmasin)
}

Irsa Moch Munawir Syahroni*, Hary Supriadi, Acep Supriadi

Master Program of Science in Development Administration, Lambung Mangkurat University, Indonesia

DOI: $10.36348 /$ SJEF.2019.v03i10.002

| Received: 26.09.2019| Accepted: 03.10.2019| Published: 14.10.2019

*Corresponding author: Irsa Moch Munawir Syahroni

\section{Abstract}

The problem of the effectiveness of the land and building tax collection system in the Banjarmasin city government which was still low. This can be seen from the low realization of land and building revenue from 2013 to 2016 which was obtained from the amount of Regional Tax Payment Deposit Slips compared to the potential amount of land and building tax in Banjarmasin, that is the amount of Tax Payable Notices issued. The objectives of this research were to find the cause of the low effectiveness of the land and building tax collection system and to identify the obstacles occurred in the collection of property taxes in Banjarmasin government. This research used descriptive qualitative method. The analysis unit in this research was Revenue Office Banjarmasin. The research's primary data source were based on the interview results to the Head of the Land and Building Tax Division, Section Head of Property Tax Collection Division, the operator of SISMIOP of Revenue Office Banjarmasin, and the interview results with 40 taxpayers, while the secondary data source came from the realization of the land and building revenue reports. Data analysis using triangulation technique and Fishbone diagram. The result showed that the effectiveness of land and building collection system in Banjarmasin government was still low as reflected by the low realization of land and building revenues after it was applied in 2013. This was because the taxpayer billing were still not optimal, the payment method was still limited, the weak enforcement of implementation and filing tax objections was complicated and took a long time.

Keywords: system effectiveness, tax collection, land and building tax.

Copyright @ 2019: This is an open-access article distributed under the terms of the Creative Commons Attribution license which permits unrestricted use, distribution, and reproduction in any medium for non-commercial use (NonCommercial, or CC-BY-NC) provided the original author and source are credited.

\section{INTRODUCTION}

The policy of regional autonomy and fiscal decentralization is an answer to the demands of the people who expect a change in all aspects of national and state life. The government is expected to be able to provide solutions to improve services to the community including by providing broad regional autonomy to local governments, which means providing space for local governments to manage available resources according to the priority needs of local communities [1]. The implementation of fiscal decentralization policy in Indonesia has begun since the issuance of Law Number 28 of 2009 concerning Local Taxes and Retributions which was passed on September 28, 2009 and became effective on January 1, 2010. This Act supersedes Law Number 18 of 1997 and the amendment to that is Law Number 34 of 2010. Based on Law Number 28 of 2009, provincial governments are given access to manage five types of taxes, while regency/municipal/city governments are given access to eleven types of taxes.
There is an expansion of the tax base such as the inclusion of catering as part of the restaurant tax, and the existence of local government flexibility in setting tax rates, another thing that is quite important in Law Number 28 Year 2009 is the submission of two types of central tax namely Duty on Land and Building Right Acquisition (BPHTB) and Land and Building Tax of Rural and Urban Areas (PBB-P2) to regional tax. This is a big change in supporting decentralization along with general understanding and international experience which shows that property taxes are better left to the regions as a source of district/city level income. According to Devas [2] most state property taxes contribute more than half of regional own-source revenues [3]. He made the PBB as a local tax, then the local government will get a large local tax so that later the local government no longer needs to take care of taxes that are of little value [4].

The transfer of land and building tax in Banjarmasin City was carried out in December 2012, and effective management was carried out starting 
January 1, 2013. Based on BAST Number BA25/WPJ.29/KP.01/2012 on December 21, 2012, Directorate General of Taxes (DJP) through banjarmasin Small Taxpayers Office (KPP Pratama Banjarmasin) has submitted the PBB-P2 database and receivables to Banjarmasin government. The submitted database is the basis of Notification of Tax Due (SPPT) issuance by the Office for Management of Regional Revenue, Finance and Assets (Dispenda) Banjarmasin.

The value of PBB-P2 receivables submitted to the city government of Banjarmasin is Rp68,849,048,619.00 with the following details:

Table-1: List of PBB-P2 Receivables in accordance with record of transfer from KPP Pratama Banjarmasin

\begin{tabular}{|r|c|r|r|r|}
\hline No & Tax Year & Beginning balance $(\mathrm{Rp})$ & Action & \multicolumn{1}{|c|}{ Ending balance $(\mathrm{Rp})$} \\
\hline 1 & 1993 & $1.841 .116,00$ & - & $1.841 .116,00$ \\
\hline 2 & 1994 & $811.517 .258,00$ & - & $811.517 .258,00$ \\
\hline 3 & 1995 & $1.450 .178 .714,00$ & - & $1.450 .178 .714,00$ \\
\hline 4 & 1996 & $891.160 .460,00$ & - & $891.160 .460,00$ \\
\hline 5 & 1997 & $514.521 .119,00$ & - & $514.521 .119,00$ \\
\hline 6 & 1998 & $477.448 .865,00$ & - & $477.448 .865,00$ \\
\hline 7 & 1999 & $843.948 .284,00$ & - & $843.948 .284,00$ \\
\hline 8 & 2000 & $943.255 .893,00$ & - & $943.255 .893,00$ \\
\hline 9 & 2001 & $1.298 .781 .767,00$ & - & $1.298 .781 .767,00$ \\
\hline 10 & 2002 & $1.404 .961 .481,00$ & - & $1.404 .961 .481,00$ \\
\hline 11 & 2003 & $2.706 .990 .643,00$ & - & $2.706 .990 .643,00$ \\
\hline 12 & 2004 & $2.184 .687 .450,00$ & - & $2.184 .687 .450,00$ \\
\hline 13 & 2005 & $3.218 .104 .623,00$ & - & $3.218 .104 .623,00$ \\
\hline 14 & 2006 & $4.430 .479 .827,00$ & - & $4.430 .479 .827,00$ \\
\hline 15 & 2007 & $5.875 .171 .414,00$ & - & $5.875 .171 .414,00$ \\
\hline 16 & 2008 & $6.784 .551 .840,00$ & - & $6.784 .551 .840,00$ \\
\hline 17 & 2009 & $7.245 .394 .628,00$ & - & $7.245 .394 .628,00$ \\
\hline 18 & 2010 & $9.365 .983 .363,00$ & - & $9.365 .983 .363,00$ \\
\hline 19 & 2011 & $9.039 .099 .164,00$ & - & $9.039 .099 .164,00$ \\
\hline 20 & 2012 & $9.360 .970 .710,00$ & - & $9.360 .970 .710,00$ \\
\hline & & Total & & $68.849 .048 .619,00$ \\
\hline
\end{tabular}

Source: LHP LKPD Banjarmasin FY of 2013

The management authority is left to the Banjarmasin city government, the land and building tax collection carried out by the Banjarmasin Dispenda is still not optimal. This can be seen from the low realization of PBB revenues from 2013 to 2016 obtained from the number of SSPD compared to the potential amount of land and building tax in Banjarmasin, namely the number of SPPT issued, with the following detailed data:

Table-2: PBB Revenue Ratio (SSPD) compared to SPPT Issuance

\begin{tabular}{|c|c|c|c|c|c|c|c|}
\hline \multirow{2}{*}{ No. } & \multirow{2}{*}{ Tax Year } & Total of SPPT Issued & \multicolumn{4}{|c|}{ SSPD Total } \\
\cline { 3 - 8 } & & Sheet & Rp & Sheet & $\%$ & Rp & $\%$ \\
\hline 1 & 2013 & 155,746 & $20,281,327,402$ & 62,009 & $39.81 \%$ & $11,770,444,327$ & $58.04 \%$ \\
\hline 2 & 2014 & 157,642 & $20,506,787,106$ & 62,493 & $39.46 \%$ & $12,617,597,411$ & $61.53 \%$ \\
\hline 3 & 2015 & 172,067 & $21,837,777,557$ & 71,674 & $41.65 \%$ & $13,374,822,255$ & $61.25 \%$ \\
\hline 4 & 2016 & 164,426 & $31,529,711,707$ & 68,832 & $41.86 \%$ & $18,896,919,282$ & $59.93 \%$ \\
\hline
\end{tabular}

Table 2 shows that the ratio of $\mathrm{PBB}$ revenues compared to SPPT issuance is relatively small at less than 50\%. The impact of the low realization of PBB revenue when compared with the potential tax, the $\mathrm{PBB}$ revenue which is one of the sources of Banjarmasin Original Local Government Revenue (PAD) is not optimal so that regional development will not be maximized. This article describes the lack of PBB revenue due to the fact that collection has not been optimal; the form of invoice submitted to the public, the method of payment and enforcement of its implementation (related to the objection process of taxpayer).

\section{METHODS}

This research uses a descriptive research model with a qualitative approach. This method was chosen by the researcher to describe or analyze a research result but was not used to make broader conclusions. Qualitative research methods are research methods used to examine natural object conditions, where researchers are key instruments, triangulation 
(combined) data collection techniques, inductive data analysis, and qualitative research results emphasize meaning rather than generalization [5]. The qualitative approach used in this study, the data and information obtained are then organized and analyzed in order to get a picture of the object of research. Data triangulation analysis tools that include triangulation of data collection methods, triangulation of data sources, and theory triangulation $[6,7]$. To support the process of classifying researchers' data using Fishbone Diagrams.

Primary data was carried out through interviews with the Head of the PBB and BPHTB Division, the Head of the PBB-P2 Billing Section, the SISMIOP operator of Banjarmasin Dispenda and the interviews with 40 taxpayers as respondent sample. Secondary data through the study of the main duties and functions of the Dispenda, organizational structure, Mayor Regulations related to PBB-P2 collection, SOP of PBB-P2 Collection, Tax-related Regulations, reports on the number of SPPT issued and the number of SSPD issued by Dispenda and LHP BPK. Qualitative research instruments known as human instruments. The term human instrument means that the researcher acts as a research instrument: formulating problems, collecting, analyzing, and testing the validity of data comprehensively $[8,9]$.

\section{RESULTS AND DISCUSSION}

The consequences of fiscal decentralization are intended so that the instruments of revenue from taxation and levies can be utilized as much as possible for the benefit of the community. In supporting the policy, the government has revised the Local Tax and Charges Law by making several changes, the latest being Law No. 28 of 2009 concerning Local Taxes and Charges (PDRD). The result of the revision was the delegation of authority on land and building tax of rural and urban areas (PBB-P2) that the management was fully delegated to the regional government. According to Law No. 28 of 2009 shows if the transfer of authority of PBB-P2 management to local governments in accordance with Article 182 paragraph 1, is carried out not later than by the district and city governments on January 1, 2014.

This policy is an effort in developing regional autonomy which is carried out through increasing the institutional capacity of regional governments, increasing the capacity of regional government apparatuses, increasing the financial capacity of regional governments, and strengthening local democracy. It is hoped that the increase in local taxing power will enable the policy to be implemented through socialization and technical assistance to increase compliance with paying local taxes and cooperation in local tax administration between the provincial, regency, and city governments. Marked the enactment of this law makes PBB-P2 from the Central Tax into
Local Taxes and is expected to be one of the important sources of PAD revenue for each region.

Thus this regulation, it is hoped that the role of the regions in supporting the national economy will be even greater. In addition, economic conditions and globalization tend to demand an active role from local governments to explore more of their regional potentials, and play a greater role in stimulating regional economic activity. However, based on research findings, it is described that the causes of the effectiveness of the PBB collection system are still low as follows:

\section{SPPT issued not all up to the taxpayer}

The SPPT (Notification of Tax Due) issued by the Banjarmasin City Dispenda includes information such as the name and address of the taxpayer, tax object number and address, bill amount, arrears amount, issue date, due date and place of payment. The SPPT does not include the legal basis for tax collection, the method of calculating the amount of tax and or discount for early payment.

Interviews with the Head of the PBB-P2 Billing Section revealed that the PBB-P2 collection or collection process began with the issuance of SPPT which was mass printed in February and delivered to each kelurahan documented by the document of handover and DHKP. Starting from the kelurahan, the SPPT was then distributed to RTs and then submitted to WP with documentation in the form of SPPT receipt. After receiving the SPPT, the taxpayer can make payments to the place of payment that has been determined and can also pay via mobile cars that operate from June until the payment due date. For taxpayers of large categories (specifically) whose tax value is above 20 million rupiahs, a direct billing is carried out by Dispenda. Whereas SPPT that cannot be submitted to taxpayer will be returned to the village and will be kept by the officer in the village. The SPPT is stored in village because taxpayer is likely to take it to the village. There is no time limit for when the SPPT is stored in the village.

Since the transfer of PBB-P2 into local tax, Banjarmasin City Dispenda in 2015 has made efforts to update the database (cleansing data) through cooperation with the village to monitor the return of SPPT issued in 2014 but not to the tax object. This was done to ensure the level of validity of the PBB-P2 database submitted by KPP Pratama Banjarmasin. However, these activities have not been accompanied by surveys and physical examinations in the field, so the results of updating the data are not yet reliable. The Dispenda has not yet carried out the data collection as regulated in the General Guidelines for Management of the PBB-P2 Director General of Fiscal Balance in 2014. The Dispenda also has not coordinated with related institutions in order to update the database, namely KPP 
Pratama Banjarmasin, water utilities (PDAM) or State Electricity Company (PLN).

Another obstacle faced by Dispenda in updating data is the absence of up-to-date maps for mapping the location of tax objects, making it difficult for field officers to conduct surveys. In addition, the limited number of human resources also makes it difficult for Dispenda to update the data. The results of the cleansing data showed that there were still SPPTs which did not reach the subject of taxation (not identified) as many as 5,306 shares valued at Rp4, 662, 239, 304.00. That is because there are still SPPTs that address unclear and complete tax objects, not on the block map, land has changed ownership and has been divided, and vacant land whose owner is unclear. Then there are still SPPTs with unclear identities of 143 tax sheets valued at Rp202, 440, 151.00 because the tax subjects are initials (Mr. X or Mr. K) and SPPT with double indications of the same tax object totaling 5 sheets worth Rp77, 955, 518.00. Based on interviews with 40 taxpayer respondents, it is known that as many as 12 respondents did not get SPPT from the village.

\section{The SISMIOP application still has many weaknesses}

SISMIOP is the main application for processing PBB-P2 databases starting from the data collection process to reporting. Based on interviews with SISMIOP operators, it is known that the application still has many weaknesses including:

a. Sales Value of Taxable Object (NJOP) calculations on SISMIOP are inconsistent. Some problems arise, such as when calculating the tax object with the equivalent specifications, the resulting NJOP value is different. Inconsistencies appear when mutations are reduced in building specifications, the NJOP is even higher. PBB fluctuations in the value of each year are also not known with certainty the calculation formula.

b. The number of characters in the address field is limited, so address information cannot be recorded in detail.

c. When processing the assignment, SISMIOP does not verify the NOP inputted with the NOP in the database. NOP is a tax object identity, is a unique number that should not be duplicated. In the process of determining both for new tax objects and due to mutations, NOPs are inputted manually so there is a potential for NOP input errors. If the inputted NOP is for the tax object that has been paid, it will reappear to the Taxpayer who actually paid the PBB bill for the tax object.

d. SISMIOP is not yet integrated with geographic information systems (SIG) for mapping tax objects;

e. Unclear ZNT determination. ZNT is a division of zones where land values are determined for each of these zones. However, the determination of ZNT in Banjarmasin is not consistent. Among them there is the same ZNT even though the location of the tax object is next to each other. The determination of the ZNT was carried out before the management of PBB-P2 was submitted to the regional government. New dispensation can change the database if there is a change in mutations from taxpayers.

\section{Payment methods are still limited}

The results of interviews with the Head of the PBB-P2 Billing Section revealed that taxpayers can make PBB-P2 payments in cash by paying directly to the Dispenda Office, the Kalsel Bank, 5 UPTDs and by traveling cars. Taxpayers have not been able to make payments at all Banks or ATMs because Dispenda has only cooperated with Kalsel Bank only. In addition, taxpayers have not been able to make payments through the designated post office or point payment. Taxpayers also have not been able to make payments by credit card, sms banking, internet banking or payment in installments in stages. The payment method is still limited because Dispenda has not made payment cooperation with several other parties such as the Post Office, payment points, other banks. The results of interviews with 40 respondents found that as many as 21 respondents wanted payment via ATM, as many as 4 respondents through internet banking, as many as 5 respondents through payment points, and as many as 2 respondents through the post office. In addition, as many as 14 respondents want payment in installments in stages.

\section{Enforcement of weak implementation}

Based on interviews with the Head of the Billing Division it is known that the Banjarmasin Dispenda has not used STPD as a tax collection document owed. The substitute mechanism used for tax collection is to use the Mayor's appeal letter. The billing process begins with the mass printing of SPPT which is then distributed to 52 villages to be subsequently submitted to the Taxpayer through the local RT Chairman. Whereas for SPPT whose value is large/potential, SPPT is directly conveyed by Dispenda officers to the Taxpayer. However, there are no criteria or limits on how much the SPPT value is categorized as large/potential, so there is no list of Taxpayer recapitulation who's SPPT is submitted directly by the Dispenda officer but only based on evidence of SPPT tears. If the taxpayers with large SPPT values have not yet been paid, the Dispenda officer will provide a Mayor's appeal letter, the contents of which are an appeal to pay the PBB in the current year and receivables for the last five years if there are PBB-P2 arrears.

The results of interviews with the Head of the PBB and BPHTB Division revealed that Dispenda had not used STPD as a tax collection document owed. This happens because if the billing is already using STPD, the follow-up of the use of the STPD must be in accordance with Law Number 19 of 2000 concerning Tax Collection by Forced Letter while the Banjarmasin Government does not yet have a bailiff. Although this 
has been regulated in Mayor Regulation Number 08 of 2013 concerning Procedures for Payment and Collection of PBB. In addition, based on the results of interviews with the Head of the PBB-P2 Billing Division, it is known that Dispenda actually has the authority to confiscate assets after several notices and then to auction them down if the taxpayer does not also pay taxes, but the implementation is not carried out due to difficult application. So far, the Dispenda has not enforced strict PBB collection for taxpayers who do not pay PBB-P2 and is only subject to a $2 \%$ monthly penalty, a maximum of 2 years for taxpayers who are late paying PBB-P2. Dispenda does not have full tax authority on tax collection and enforcement of its implementation, for example by deducting employee salaries and deducting from pension funds to pay PBB$\mathrm{P} 2$. In addition, the number of human resources conducting billing only amounted to three people, that number is still inadequate when compared to 52 kelurahan in Banjarmasin. The results of interviews with 40 respondents also found that as many as 23 respondents stated that there was no Dispenda officer who billed or acted on the Taxpayer if the Taxpayer did not pay PBB-P2.

\section{Filing a tax complaint is complicated and requires a long time}

Based on interviews with the Head of the PBB-P2 Billing Section, it is known that the mechanism that can be carried out by Taxpayers who object to the value of PBB-P2 determination is by making their own objection letters and then submitting them to the counters to be processed in the billing and data collection section. Dispenda does not provide forms that can be used by taxpayers to facilitate filing tax objections, and based on Regional Tax Service Standards, the time required to process complaints against taxpayers is for one year. Besides that, in Banjarmasin City Government there is no special city council established to handle PBB-P2 administrative complaints and also there is no special court regarding tax administration. The results of identification using the Fishbone Diagram of the causes of the low realization of $\mathrm{PBB}$ payments and enforcement of their implementation, the causes can be classified into four groups, namely: a. Material group

The PBB-P2 database submitted from the DJP through the KPP Pratama Banjarmasin is invalid. Updating the database that has been carried out by the Banjarmasin City Dispenda is still not optimal. With the database that is still not valid, the SPPT that is published annually will not be entirely up to taxpayer.

b. Machine and equipment group

The SISMIOP application used for PBB-P2 management still has many weaknesses. Such conditions will affect the accuracy of the data starting from the inconsistent NJOP calculation, the complete address of the taxpayer, the possibility of re-determination of PBB-P2 for the taxpayer who has already paid, then SISMIOP has not been integrated with the SIG application, making it difficult to find out directly the location of the tax object, and also the existence of ZNT inconsistencies in value.

c. Man power group

1. The number of billing officers is lacking so that the number of kelurahans is 52 , the billing process is less than optimal.

2. Dispenda does not have a bailiff's officer, so the billing mechanism with STPD cannot be implemented.

3. Lack of coordination between Dispenda with other relevant agencies such as KPP Pratama, PDAM and PLN mainly related to tax object database updating activities.

d. Method group

1. Payment methods used are still limited. The payment method used is still in cash and can only be done in a few places.

2. Dispenda has not done billing by using STPD so enforcement of its implementation is still weak.

3. Filing an objection to the establishment of the $\mathrm{PBB}$ is complicated and requires a long time, namely for one year.

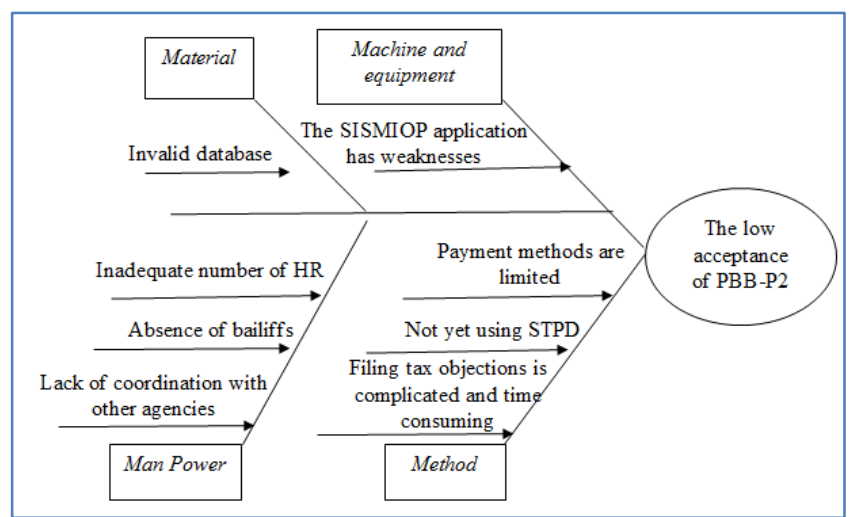

Fig-1: Classification of the causes of the problem of low PBB revenues with the Fishbone Diagram 
Figure 1, can be explained the relationship or relationship between causes. The low acceptance of PBB-P2 can be caused by two main factors, namely the mechanism of PBB-P2 collection has not used the Notice of Local Tax Collection (STPD) and the database is invalid. The fact that PBB-P2 has not been collected using STPD indicates that enforcement of the PBB-P2 collection is still very weak. In the absence of strict enforcement of the implementation, the Taxpayer will feel that paying the PBB is not a priority because even though the Taxpayer has not paid the PBB for many years there are no severe consequences and will only incur a $2 \%$ fine if later he will also pay the PBB if the object the land or building will be sold. Dispenda has not used the collection mechanism with STPD because it does not have a bailiff and the number of HR tax collectors is still inadequate. While the PBB database is invalid because the SISMIOP application still has many weaknesses and a lack of coordination with other relevant agencies to update the database as well as inadequate numbers of human resources to carry out survey data updates. The low validity of the PBB database also shows that the invoice (SPPT) made by Dispenda is still not optimal.

Constraints on payment methods that are still limited also affect the PBB-P2's low revenue factor because the ease of payment and payment also influences the taxpayers to immediately pay their taxes. Another obstacle is that filing an objection is complicated and requires a long time, this can cause taxpayers who want to immediately pay the PBB but feel objected to the length of the process of filing an objection to be reluctant to file an objection and finally decide not to pay taxes because they feel they are not treated fairly. This can have a significant effect on taxpayers whose PBB value is quite large.

\section{CONCLUSION}

The effectiveness of PBB-P2 collection system in Banjarmasin City Government is still low as illustrated by the low realization of PBB revenue after it was applied in 2013. This is because collections (SPPT) are still not optimal, payment methods are still limited, weak enforcement and complicated tax objections and requires a long time. Factors that hinder the collection of PBB-P2 in Banjarmasin City Government are divided into three parts. First, collections (SPPT) are still not optimal due to the low validity of the taxpayer dabase and tax objects contained in the SISMIOP application. That is because Dispenda has not updated data on all taxpayers and tax objects either through surveys or in coordination with relevant agencies such as PDAM or PLN. In addition, the SISMIOP application that is used still has many weaknesses and inadequate numbers of human resources to carry out survey data updates.

Second, the method of payment is still limited to only the counters at the Dispenda Office, UPT offices, mobile cars and through the Kalsel Bank so that taxpayers do not have the option of making tax payments which they think are the easiest and most convenient due to the Dispenda not cooperating with the perception bank or other parties and Dispenda have not implemented a payment system using credit cards and online payment or payment systems in a gradual manner. Third, the weak enforcement of the implementation due to not yet implemented billing through the STPD mechanism. This happens because Dispenda does not have a bailiff and the number of tax collector HR is still inadequate. 4) Filing a tax objection is complicated and requires a long time. This happens because the Dispenda does not provide a special form that can make it easier for the Taxpayer to submit a tax objection, and the time required to resolve the tax objection in accordance with the SOP of Services is one year. In addition, the city of Banjarmasin also does not have a special city council and a special court related to the PBB collection.

\section{REFERENCES}

1. Djalil, R. (2014). Akuntabilitas Keuangan Daerah, Implementasi Pasca Reformasi. Jakarta: Rmbooks.

2. Devas, N., \& Binder, B. (1989). Financing local government in Indonesia(Vol. 84). Ohio University Press.

3. Mardiasmo. (2002). Otonomi dan Manajemen Keuangan Daerah. Yogyakarta: Andi.

4. Mardiasmo. (2011). Perpajakan (edisi revisi). Jakarta: Andi.

5. Moleong, L. J. (2004). Metodologi Penelitian Kualitatif. Bandung: Remaja. Rosdakarya.

6. Sugiyono. (2012). Metode Penelitian Kuantitatif, Kualitatif dan $R \& D$. Bandung: Alfabeta.

7. Denzin, N. K., \& Lincoln, Y. S. (2009). HandBook of Qualitative Research. Yogyakarta: Pustaka Pelajar.

8. Afifuddin., \& Ahmad, B. (2009). Metodologi Penelitian Kualitatif. Bandung: Pustaka Setia.

9. Undang Nomor 28 Tahun. (2009). Mengenai Pajak Daerah dan Retribusi Daerah. 